\title{
STRATEGIC PERSPECTIVES FOR GEORGIAN BUSINESS - AN ANALYSIS FOR MEDIUM-SIZED ENTERPRISES IN EU AND GEORGIA
}

\begin{abstract}
Small and medium-sized enterprises (SMEs) belong to most important factors which drive the economic development. The strength of the economic system of a given country is based on the potential of SMEs as they substantially contribute to employment and national income. SMEs may be perceived as a catalyst for economic growth. If companies cooperate with larger enterprises, they contribute to the efficient use of joint resources, information and technology and knowledge. SMEs have also an impact on the growth of gross domestic product, the formation of the middle class, and the increase of economic and political stability. Welldeveloped and strong sector of SMEs significantly contribute to export and import increasing the level of prosperity on a national scale. It is also important to take into account that the culture of enterprises from this sector, the way people identify with the place they work, their founding purpose may raise the organizational culture and foster achieving the overall organization goals. If the employees of SME have a strong sense of their duties and values they may guide the culture of the organization and have a positive impact on other enterprises with which they cooperate.

In the first part of the article the authors present the experience of SMEs in the EU, in the second part they discuss the main directions of the development of SMEs in Georgia based on the analysis of statistical data. The article ends with conclusions taking into account strategic priorities for SME development in Georgia.
\end{abstract}

Keywords: SMEs, development, EU, Georgia, Global business, enterprise

\section{INTRODUCTION}

SMEs play an important role in the economy. As globalization proceeds, transition and developing countries and their enterprises face major challenges in strengthening their human and institutional capacities to take advantage of trade and investment opportunities. This has become a top priority on the global development agenda over the past few years. Small and medium-sized enterprises (SMEs) are a very heterogeneous group. SMEs are found in a wide array of business activities, ranging from the single artisan producing agricultural implements

\footnotetext{
${ }^{1}$ Agnieszka Rzepka, Ph.D, Department of Economics and Management of Economy, Faculty of Management, Lublin University of Technology, Lublin, Poland, email: a.rzepka@ pollub.pl (Author for correspondence)

${ }^{2}$ Ioseb Masurashvili, Doctor in Economics \& Management, Head of Innovation Management Center at Javakhishvili Tbilisi State University. Professor at Georgian Technical University, Founder \& Director of Venture Business Center at GTU (Georgia); e-mail: ioseb.masurashvili@tsu.ge
} 
for the village market, the coffee shop at the corner, the internet café in a small town to a small sophisticated engineering or software firm selling in overseas markets and a mediumsized automotive parts manufacturer selling to multinational automakers in the domestic and foreign markets. The owners may or may not be poor; the firms operate in very different markets (urban, rural, local, national, regional and international); embody different levels of skills, capital, sophistication and growth orientation, and may be in the formal or the informal economy.

In developed countries (including in the EU), small and medium enterprises occupy a large contribution in the operating enterprises, create over 50\% of total turnover of the entrepreneurial sector and two from in each three jobs in the private sector. Organization for Economic Cooperation and Development (OECD) countries, over 99\% of companies are small and medium enterprises and create an average $2 / 3$ of gross domestic product (GDP). In developing and transition economies over $90 \%$ of the total number of enterprises are small and medium enterprises, but their share in the GDP is generally quite low - in many cases less than $20 \%^{3}$.

SME products and services "invisible" or less noticeable are characterized by high level of reliability and viability, have significant export market share, are global competitors and great contribution to the success in country.

A major factor in the formation of small businesses is current legislative environment in Georgia. After the second half of the 1990s in Georgia there were made significant efforts for the establishment of institutional basis for of SMEs.

In recent years, Georgia has made significant reforms, including economic reforms, whose main objective was creating good environment for doing business and for foreign direct investments, by liberalizing the economy, reducing the administrative barriers and tax burden, improving public services, fight corruption, and in other ways. As a result of these reforms, Georgia has high economic growth rates. In addition, significantly increased foreign direct investments in the country. Economic policy has been positively evaluated by the various of rating agencies and international financial institutions and appropriate results are were reflected in the indices and in the ratings, which are rated the economic freedom of countries ${ }^{4}$.

The first part of the article discusses the experience in the SME-s-related in European Union, the second part the paper discusses directly main directions of development of SMEs in Georgia on the basis of statistical data analysis and it provides strategic priorities of development of SME's in Georgia.

\section{SMES - EUROPEAN EXPERIENCE}

Micro, small and medium-sized enterprises (SMEs) are the engine of the European economy. They are an essential source of jobs, create entrepreneurial spirit and innovation in the EU and thus crucial for fostering competitiveness and employment ${ }^{5}$.

\footnotetext{
${ }^{3}$ Dialogue on «SME Policy» with regard to the multilateral framework of the Eastern Partnership 2010, p. 45.

${ }^{4}$ A. Rzepka, I. Masurashvili, Current state of the Business Administration in Georgia and his role in Global Economy, ScieConf2014, pp. 79-84.

${ }^{5}$ European Commission, Enterprise and Industry Publications, 2003, p. 3.
} 
On November, 2015, The European Commission released an annual report on European SMEs (2014/2015). This report has been prepared in 2015 for the European Commission, Directorate-General for Internal Market, Industry, Entrepreneurship and SMEs; Directorate H: COSME Programme; Unit H1: COSME Programme, SME Envoys and Relations with EASME by the consortium composed of CARSA, PwC Luxembourg, Innova SpA, The University of Manchester, Manchester Institute of Innovation Research, London Economics, DIW Berlin, DIW Econ ${ }^{6}$.

This report provides an overview of the past and forecasted performance of SMEs from 2008 to 2016, and reviews in greater detail the contribution of SMEs to employment creation. SMEs are ubiquitous, and in 2014 accounted for $99.8 \%$ of all enterprises in the non-financial business sector in the EU28. For every $\mathrm{km}^{2}$ of land surface the EU has an average of 5 SMEs. Moreover, in 2014 SMEs employed almost 90 million people - 67\% of total employment, and generated $58 \%$ of the sector's value added.

Almost all SMEs (93\%) are micro SMEs employing less than 10 people. About three quarters of SMEs are active in the five key sectors: "wholesale and retail trade", "manufacturing", "construction", "business services" and "accommodation and food services".

In particular, SMEs in construction, and, to a somewhat lesser extent, in manufacturing, were hit hard by the economic and financial crisis. Employment in these two sectors in 2014 was still respectively $17 \%$ and $11 \%$ below 2008 levels, whereas value added in construction remained $18 \%$ below its 2008 level and in manufacturing has almost crawled back to where it stood in 2008. In contrast, SMEs in the "accommodation and food services" and the "business services" domains benefited from robust growth in these sectors.

It's known that SMEs are defined as businesses which employ less than 250 people and have an annual turnover of less than EUR 50 million, and / or their balance sheet total is less than EUR 43 million. They comprise three categories of enterprises, namely micro, small, and medium-sized enterprises (Table 1).

Table 1. EU definition of SMEs

\begin{tabular}{|l|c|c|c|}
\hline & Employees & Turnover or & \multicolumn{1}{|c|}{ Balance sheet total } \\
\hline Micro SME & $<10$ & $<€ 2$ million & $<€ 2$ million \\
\hline Small SME & $<50$ & $<€ 10$ million & $<€ 10$ million \\
\hline Medium-sized SME & $<250$ & $<€ 50$ million & $<€ 43$ million \\
\hline
\end{tabular}

Source: Own study was based on: Commission Recommendation of 6 May 2003 concerning the definition of micro, small, and medium-sized enterprises.(2003/361/EC), Official Journal of the European Union, L 124/36, 20 May 2003.

More than 22 million SMEs were active in the EU28 in 2014. They employed almost 90 million people. They accounted for $58 \%$ of the value added generated by the EU28 nonfinancial business sector.

${ }^{6}$ Annual Report on European SMEs - 2014/2015, http://ec.europa.eu/DocsRoom/documents/16341/attachments/ 2/translations 
In 2014, 22.3 million SMEs were active in the non-financial business sector across the EU28 (table 2). The non-financial business sector consists of all sectors of the economies of the EU28 or Member States, except for financial services, government services, education, health, arts and culture, agriculture, forestry, and fishing. SMEs account for $99.8 \%$ of all enterprises in this sector.

Table 2. SMEs: number of enterprises, employment, and value added in the EU28 in 2014

\begin{tabular}{|c|c|c|c|c|}
\hline & Micro & Small & Medium & SMEs \\
\hline $\begin{array}{c}\text { Enterprises } \\
\text { (Number) }\end{array}$ & $20,710,324$ & $1,373,365$ & 224,811 & $22,308,500$ \\
\hline$\%$ & $92.7 \%$ & $6.1 \%$ & $1.0 \%$ & $99.8 \%$ \\
\hline $\begin{array}{c}\text { Persons Employed } \\
\text { (Number) }\end{array}$ & $39,274,088$ & $27,452,716$ & $23,257,412$ & $89,984,216$ \\
\hline$\%$ & $29.2 \%$ & $20.4 \%$ & $17.3 \%$ & $66.9 \%$ \\
\hline $\begin{array}{c}\text { Value added } \\
\text { (EUR billion) }\end{array}$ & 1,358 & 1,169 & 1,188 & 3,715 \\
\hline$\%$ & $21.1 \%$ & $18.2 \%$ & $18.5 \%$ & $57.8 \%$ \\
\hline
\end{tabular}

Source: Own study was based on:Annual Report on European SMEs - 2014 /2015.

On October 15, 2012, the European Commission released an annual report on small and medium-sized enterprises in the European Union. The report entitled "EU SMEs in 2012: at the crossroads, Annual report on small and medium-sized enterprises in the EU, 2011/12" was prepared by ECORYS Nederland $\mathrm{BV}^{7}$. The report confirmed that despite challenging environment created by the global economic crisis, small and medium-sized enterprises are the backbone of the EU economy. In 2012 small and medium-sized enterprises accounted for $99,8 \%$ of non-financial enterprises. Out of the total of 20.7 million SMEs the overwhelming majority $(92.2 \%)$ were micro-enterprises, $6.5 \%$ were small enterprises, and $1.1 \%$ were classified as medium sized enterprises. According to this study, in 2012 large enterprises accounted for just $0.2 \%$ enterprises operating in the EU's non-financial sector. In 2012, small and medium size enterprises provided about $58.1 \%$ of the total Gross Value Added (microenterprises $-21.2 \%$, small enterprises $-18.5 \%$, and medium-sized enterprises $-18.4 \%$ all regard employment, the report shows about $67.4 \%$ of jobs in the non-financial sector of the EU economy were provided by the SME sector (ECORYS 2012). Moreover, according to a study published by the European Commission, 85\% of net new jobs in the EU between 2002 and 2010 were created by small and medium sized enterprises. During this period net employment in the EU economy grew substantially, by an average of 1.1 million new jobs each year ${ }^{8}$.

\footnotetext{
${ }^{7}$ European Commission 2012. EU SMEs in 2012: at the crossroads, Annual report on small and medium-sized enterprises in the EU, 2011/12" was prepared by ECORYS Nederland BV. Rotterdam.

${ }^{8}$ EIM Business\&Pilicy Research 2011. Do SMEs create more and better jobs? Zoetermeer, November 2011.
} 
Strategic perspectives for Georgian business...

Almost all SMEs (93\%) are micro SMEs employing less than 10 people. About three quarters of SMEs are active in the five key sectors: "wholesale and retail trade", "manufacturing", "construction", "business services" and "accommodation and food services".

The outlook for the future performance of SMEs in the EU28 is positive, and somewhat stronger than in 2014 but remains uneven (table 3).

Table 3. 2015 and 2016 forecasts of annual growth in SME performance indicators - EU-28

\begin{tabular}{|l|c|c|c|c|}
\hline $\begin{array}{l}\text { Size } \\
\text { class }\end{array}$ & Indicator & $\begin{array}{c}\text { \% change } \\
2013-2014\end{array}$ & $\begin{array}{c}\text { \% change } \\
2014-2015\end{array}$ & $\begin{array}{c}\text { \% change } \\
2015-2016\end{array}$ \\
\hline \multirow{3}{*}{ Micro } & Enterprises & 1,2 & 0.5 & 0.7 \\
\cline { 2 - 5 } & Value Added & 3.2 & 2.9 & 3.3 \\
\cline { 2 - 5 } & Employment & 1.3 & 0.5 & 0.8 \\
\hline \multirow{3}{*}{ Small } & Enterprises & 0.8 & 0.7 & 0.8 \\
\cline { 2 - 5 } & Value Added & 3.3 & 3.1 & 3.5 \\
\cline { 2 - 5 } & Employment & 1.0 & 0.8 & 0.9 \\
\hline \multirow{3}{*}{ SMEdium } & Enterprises & 0.9 & 0.9 & 1.2 \\
\cline { 2 - 5 } & Value Added & 3.3 & 3.8 & 4.2 \\
\cline { 2 - 5 } & Employment & 1.3 & 1.2 & 0.3 \\
\hline & Enterprises & 1.2 & 0.5 & 3.7 \\
\cline { 2 - 5 } & Value Added & 3.3 & 3.3 & 0.9 \\
\cline { 2 - 5 } & Employment & 1.2 & 0.8 & \\
\hline
\end{tabular}

Source: Own study was based on: Annual Report on European SMEs - 2014 /2015.

For the years 2015 and 2016, annual growth of 3.3\% and 3.7\% is expected for EU28 SME value added. In contrast, employment and number of enterprises are forecast to lag behind, with growth in 2015 and 2016 of roughly $0.8 \%$ and $0.9 \%$, and $0.5 \%$ and $0.7 \%$ respectively. Looking at size-class differences, medium-size SMEs are forecast to slightly outperform small and micro enterprises in both 2015 and 2016 and across all three indicators. Large firms are expected to follow a similar pattern, although their expected growth is lower in the case of value added, employment and number of firms.

\section{SME IN GEORGIA}

The situation in Georgia is positive following progress with the Deep and Comprehensive Free Trade Agreements with the EU, with reforms that foster the economic growth. Negative consequences resulting from the regional crisis decreased the external demand for products and services and tourism and led to economic slowdown since the second half of $2014^{9}$. However, the positive outcome of DCFTA is being observed ${ }^{10}$.

\footnotetext{
${ }^{9}$ Z. Olesiński, A. Rzepka, A. Sabat, Sieci powiązań we wspótczesnej gospodarce, Texters, Warszawa 2016, s. 118.

${ }^{10} \mathrm{http} / / /$ eur-lex.europa.eu/legal-content/EN/TXT/PDF/?uri=CELEX:22014A0830(02)\&from=EN (20.11.2016).
} 
Georgia has maintained a well-capitalized and soundly managed banking sector despite the recent slowdown in economic activity and weaker credit growth. Sector-wide capital adequacy ratio stands at 19\% (in Basel standards), what is higher than the regulatory minimum of $12 \%$. The NPL ratio, defined according to the international standards (loans in arrears over 90 days), is one of the lowest among the peer countries and it stands at 3.4\%.

SMEs are the backbone of the Georgian economy.

SME definitions differ from institution to institution in Georgia. Therefore, the compilation of statistics on SMEs comparable across sectors and establishments represents a challenging task. The National Statistics Office of Georgia ${ }^{11}$ classifies enterprises as small (or medium-sized) if the number of employees does not exceed 20 (100) and the average annual turnover is up to 0.5 (1.5) million Gel. For taxation purposes, the status of a small business may be granted to a natural person whose gross income from economic activity during a calendar year does not exceed Gel 100 000. As for the financial sector, measures for defining businesses by size are quite diverse among the several market players, some utilise total exposure to the client, turnover measures, annual sales or combination of them.

The Economics Department of the European Investment Bank has recently conducted a Bank Lending Survey among main financial institutions in the Georgian market. Information were collected on lending conditions, availability of different financial products and credit extensions to corporates, particularly to SMEs. The survey included questions related to recent credit developments, demand and supply factors that affect credit growth, availability of various financial instruments, breakdown of loan portfolio by sectors/maturity/purpose, and perception of credit conditions. The respondents provided information according to their definition of SMEs. Six respondents were chosen from the financial intermediaries in Georgia ( 5 commercial banks and one microfinance institution). The survey covered $75 \%$ of banking sector assets and approximately $65 \%$ of banking sector SME portfolio. Some of the key results of the survey are reported in this section and in the following sections ${ }^{12}$.

The SME sector has a special role to play in the process of transition of the economies of the Georgia. However, although SMEs make up the large majority of firms in the Georgia many are still restricted to niche markets with little growth potential. SMEs account for $94 \%$ of enterprises in Georgia. However, with their concentration in the micro segment and subsistence activities, their contributions to employment and turnover are much lower. The employment contribution, for example, is $43 \%$ in Georgia ${ }^{13}$.

Access to finance is one of the main obstacles to doing business as perceived by SMEs. Other factors highlighted by the Enterprise Survey ${ }^{14}$ include political instability, corruption, and tax rates. The survey was conducted in 2012 when the country was going through political changes, therefore, they must be compared to data of today when the access to finance is much bigger.

\footnotetext{
${ }^{11}$ www.geostat.ge

${ }^{12}$ Neighbourhood SME financing: Georgia. Report. European Investment Bank February 2016, p. 15.

${ }^{13}$ OECD Small Business Act.

${ }^{14}$ http://ebrd-beeps.com/reports/beeps_v_report/
} 
With limited access to external funding, SMEs rely heavily on internal sources of funding and retained earnings. In Georgia over $70 \%$ of investments in fixed assets and $80 \%$ of working capital are financed with internal resources ${ }^{15}$. Bank lending makes a small contribution to total financing needs which for both fixed assets and working capital are predominantly met by internal finance.

The quality of the business environment is highly diverse in the East. Based on the World Bank's Doing Business 2016 report (table 4), Georgia has the ease of doing business, in places itself on $24^{16}$. Getting credit is not the most serious problem facing businesses in any of the countries. For Georgia, doing business indicates that closing a business and getting electricity are the most important problems. Other aspects of the business environment in Georgia are generally positive and the country scores particularly well for dealing with licenses, registering property and starting a business ${ }^{17}$.

Table 4. Doing Business rank in Georgia out of 189 countries

\begin{tabular}{|l|c|}
\hline Starting a business & 6 \\
\hline Dealing with construction permits & 11 \\
\hline Getting electricity & 62 \\
\hline Registering property & 3 \\
\hline Getting credit & 7 \\
\hline Protecting minority investors & 20 \\
\hline Paying taxes & 40 \\
\hline Enforcing contracts & 13 \\
\hline Trading across borders & 78 \\
\hline Resolving insolvency & 101 \\
\hline
\end{tabular}

Source: Own study was based on: Doing Business 2016 Going Beyond Efficiency.

The index published in Economic Freedom of the World measures the degree to which the policies and institutions of countries are supportive of economic freedom. The cornerstones of economic freedom are personal choice, voluntary exchange, freedom to enter markets and compete, and security of the person and privately owned property. For two data points are used to construct a summary index and to measure the degree of economic freedom in five broad areas:

- size of government: expenditures, taxes, and enterprises;

- legal structure and security of property rights;

- access to sound money;

${ }^{15}$ D. De Clercq, H. Sapienza, H. Crijns, The internationalization of small and medium firms, "Small business economics" 2005, No. 24, p. 409-419.

16 Doing Business 2016 Going Beyond Efficiency, http://www.doingbusiness.org/ /media/GIAWB/ Doing\%20Business/Documents/Annual-Reports/English/DB16-Full-Report.pdf (14.05.2016).

${ }^{17}$ http://ebrd-beeps.com/reports/beeps_v_report/. 
- freedom to trade internationally; and

- regulation of credit, labour, and business.

This year's EFW index ranks 159 countries and territories. In 2016 year's ranking, which is based on 2014 data, Hong Kong is again number one, Georgia is tied for fifth, and the United States ranked $16^{\text {th }}$ for the second year in a row ${ }^{18}$.

By Global Entrepreneurship Index, from 131 countries in the world's, Georgia has the 81th place - index of $28.7^{19}$.

Small and medium sized enterprises (SMEs) dominate Georgian business sector in terms of number of registered companies, however the relative production and turnover figures are much lower. According the National Statistics Office Georgia ${ }^{20}$ the SME segment accounted for $18 \%$ of total private sector turnover and $19 \%$ of total production in Q1 $2016^{21}$.

Figure 1. SME production by sectors

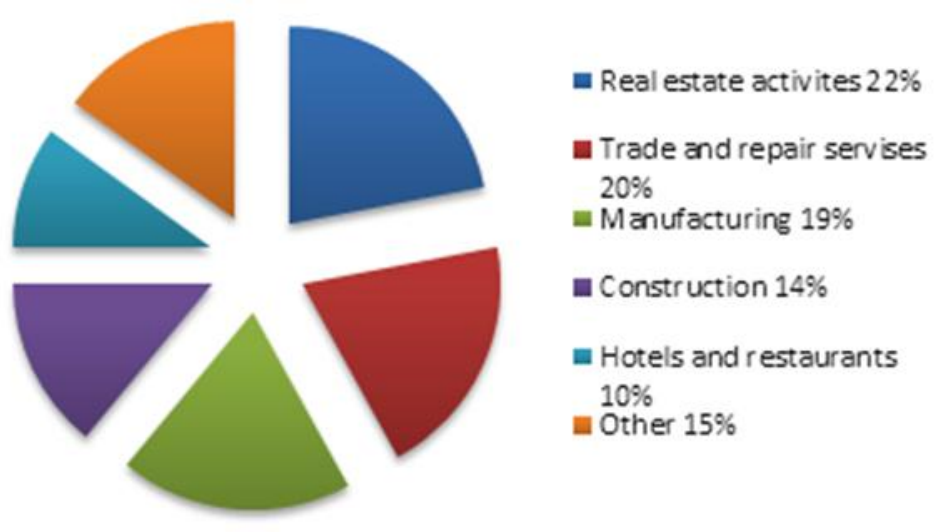

Source: Own study was based on: Economic Freedom of the World: 2016 Annual Report. http://cbw.ge/economy/georgia-among-top-five-economically-free-countries/ https://www.fraserinstitute.org/studies/economic-freedom-of-the-world-2016-annual-report

To the contrary, SMEs account for $40 \%$ of total business sector employment. Average salaries for employees in SMEs are lower than average salaries of employees in large businesses. As of Q1 2016, average monthly salary in a small business entity was less than

18 Economic Freedom of the World: 2016 Annual Report, http://cbw.ge/economy/georgia-among-top-fiveeconomically-free-countries/; https://www.fraserinstitute.org/studies/economic-freedom-of-the-world-2016-annualreport

${ }^{19}$ Global Entrepreneurship Index - 2016, https://thegedi.org/global-entrepreneurship-and-development-index/

${ }^{20}$ Official business sector statistics does not cover following sectors: financial intermediation; public administration; household production activities intended for own use; retail trade on markets and fairs.

${ }^{21}$ www.geostat.ge 
half of the compensation in large enterprises, while average monthly earnings in medium enterprises amounted to $68 \%$ of large companies ${ }^{22}$.

The services sector accounts for large part of the small and medium-sized enterprises. Looking at the sectoral breakdown, SMEs are more involved in production processes in real estate, trade and manufacturing sectors (see figure 1).

Most of the SMEs business is oriented toward the local market. A small share of SMEs is involved in direct export activities ${ }^{23}$. Inter alia, small volumes of production make it more costly for SMEs to explore export opportunities and expand in foreign markets. In addition, the share of firms with internationally recognized quality certification is relatively low.

The quality of the business environment to a large degree reflects the underlying institutional framework for SMEs. Assessment and recommendations for the institutional framework has been made under the OECD's initiative on the small business act.

In Georgia the legal framework has been improved, particularly with regards to private credit bureau information. Bank lending is constrained by high interest rates and collateral requirements. Microfinance institutions are widespread but lack capital, while other non-bank financial institutions are less developed. The legal framework for venture capital is in place but activity remains low. Looking forward, Georgia has formulated an SME strategy for implementation over 2016-2020 24 .

Table 5. SME Policy Index Scores in Georgia

\begin{tabular}{|l|l|}
\hline Bank Financing & 3.3 \\
\hline Non-bank financing & 3.7 \\
\hline Venture capital & 1.7 \\
\hline Bankruptcy and second chance & 2.9 \\
\hline Access to Finance & 3.6 \\
\hline Standards and technical regulations & 4.2 \\
\hline Legal and regulatory framework & 4.3 \\
\hline Operational environment & 4.3 \\
\hline Regulatory framework & 3.5 \\
\hline Public procurement & 4.0 \\
\hline Innovation policy for SMEs & 2.9 \\
\hline Enterprise skills & 3.0 \\
\hline Support measures for SME start-ups & 3.7 \\
\hline
\end{tabular}

Source: Own study was based on:OECD Small Business Act.

In Georgia the number of registered new enterprises rapidly increases. In 2007 this indicator was 227.2 thousand, in 2009 - reached 409.5 thousand, in 2011 - 506.3 thousand,

\footnotetext{
${ }^{22}$ www.geostat.ge (12.09.2016).

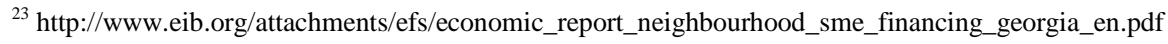

${ }^{24}$ Ibidem.
} 
and in 2013 - increased and was 593.2 thousand. Also constantly growing specific share small and medium enterprises (SMEs) in the total number of enterprises (table 5$)^{25}$.

Despite the improvement in the general business environment, by viewpoint for development SMEs in Georgia are the same challenges, which in many developing countries. Although small and medium-sized enterprises comes the largest part existing enterprises, their contribution to GDP is still very low.

SME activity is especially noticeable in Tbilisi, Imereti, Qvemo Qartli and Achara region, than, when Racha-Lechxumi amd Qvemo Svaneti, Samcxe-Javakheti and Guria are very passive in small businesses activities. It is very important is the fact that SMEs are playing a negligible role in economic development of country. Particularly are high SMEs retardation in the transfer of innovative technology ${ }^{26}$.

Government of Georgia attaches great importance to the process of economic development of small and medium entrepreneurs and aimed at further improvement of the business environment, which will contribute to the growth and development of small and medium enterprises. The clear example "The small and medium Entrepreneurship Development strategy for the years 2016-2020"27 and also the Government program "A strong, democratic, United Georgia" ${ }^{28}$ (Which periodically updated).

Development private sector and especially support development small and medium entrepreneurs one of the government's economic policy priority which is also reflected in "The social-economic development strategy - Georgia 2020 (June, 2014)"29.

The Georgian government devotes special attention to increase competitiveness to the private sector and especially small and medium enterprises in the context of Georgia-EU Associate Agreement (which is an integral part of the Deep and Comprehensive Free Trade Agreement - DCFTA $)^{30}$.

DCFTA - requirements adaptation and their performance is especially important for Georgia, to make the businesses opportunities will be able maximize the use of the export potential. Accordingly, in addition to legal and institutional convergence, the great importance is attached of the private sector, including small and medium enterprises by DCFTA-'s requirements.

"The small and medium Entrepreneurship Development strategy for the years 2016-2020", which is based on European Small Business Act "Think Small First the" ${ }^{\text {"31 }}$ principle. The main objective is to strengthen the competitiveness of small and medium enterprises sector, it makes a basis for the creation of an inclusive and sustainable for economic growth in. The strategy sets out goals that are to be achieved by 2020 .

\footnotetext{
${ }^{25}$ www.geostat.ge

${ }^{26}$ Ibidem.

${ }^{27}$ http://gov.ge/files/439_54422_706524_100-1.pdf;

http://www.ge.undp.org/content/dam/georgia/docs/strategicdocs/UNDP_GE_CPD_2016-2020.pdf

${ }^{28} \mathrm{http}: / /$ gov.ge/index.php?lang_id=geo\&sec_id $=68$

${ }^{29} \mathrm{https}: / /$ www.adb.org/sites/default/files/linked-documents/cps-geo-2014-2018-sd-01.pdf

${ }^{30} \mathrm{http} / / /$ eur-lex.europa.eu/legal-content/EN/TXT/PDF/?uri=CELEX:22014A0830(02)\&from=EN

${ }^{31} \mathrm{http}: / /$ europa.eu/rapid/press-release_IP-08-1003_en.htm
} 
Strategic directions and policy appropriate measures, which are reflected in this Strategy, developed for the analysis of the economic situation, SMEs institutional and business environment analysis, considering of existing assessments and recommendations. The effective implementation of the relevant policy measures should provide a strategy to reach their goals in $2020^{32}$. Specific measures are set out in the attached Action Plan. The strategy also involves the monitoring and evaluation mechanisms. "The small and medium Entrepreneurship Development strategy for the years 2016-2020" developed active cooperation for Organization Economic Cooperation and Development (OECD) and of the support the German International Cooperation Society (GIZ).

According to the Georgian National Statistics Service of the SMEs statistical results are as follows: in 2014 the number of existing enterprises was 70 760, from which 6170 were medium, and 60640 were small enterprises. Accordingly, 94\% of existing enterprises (9\% medium, $85 \%$ - small) occupied SMEs.

In 2006-2014 turnover of SMEs increased by $269 \%$ - from 2.4 billion GEL to 9 billion GEL. At the same time product output increased by $269.7 \%$ - from 1.4 billion GEL to 5.2 billion GEL. The largest share falls on Tbilisi.

In 2006-2014 the share of the value added created by SME was changed in gross value added enterprises, however it didn't exceed 20\%, except in 2011 and 2014 when this indicator amounted respectively $21.8 \%$ and $21.1 \%$. The largest share of value added $(71.1 \%)$ was created in Tbilisi.

The share in GDP was low (18\% - in 2014), thereby this proved that SME still cannot play an important role in the economy.

In 2006-2014 employment in SMEs increased by 53.7\% - from 168.7 to 259.4 thousand. In this period number of hiring employees increased by $58 \%$ - from 148.1 thousand to 233.9 thousand. However, in SMEs the share of persons employed in enterprises was high (in 2014 - 43.8\%), especially taking into account, that SMEs the share was high (94\%) and 63\% employed in Tbilisi.

In 2006-2014 medium-sized enterprises average monthly salaries of employees increased 3.4 times from $185 \mathrm{Gel}$ to $636.9 \mathrm{Gel}$, but of small enterprises increased 2.7 times - from 141.4 Gel to 375.2 Gel.

During this period, small and medium-sized enterprises of intermediate consumption increased by $220 \%$ from 767.6 million GEL to 2.5 billion GEL, and investments in fixed assets - by $208 \%$ - from 272.4 million to 839.5 million Gel. In Tbilisi the largest share of investment was in fixed assets (62\%). 2007-2014 - from 1.9 to 7.1 billion GEL ${ }^{33}$.

In the forthcoming years the main policy priorities for small and medium-sized enterprises should include:

\footnotetext{
${ }^{32}$ Y. Babych and M. Fuenfzig, An Application of the Growth Diagnostics Framework: The Case of Georgia (Working Paper No. 001-12). International School of Economics at TSU, Tbilisi, Republic of Georgia, 2012, http://ideas.repec.org/p/tbs/wpaper/12-001.html.

${ }^{33}$ www.geostat.ge
} 
- $\quad$ an improved access to financing;

- an improved access to entrepreneurial trainings and EU practices accordingly;

- developing support measures to promote innovative entrepreneurship;

- developing new instruments in order to promote export.

Goals and objectives of strategy for development Georgian small and medium-sized enterprises should definitely create favourable environment for the enterprises development, raise their capacity, competitiveness and innovation. This would result in a growth of the number of workplaces, and therefore contribute to sustainable economic growth of the whole country. The objectives of "Small and Medium Enterprise Development Strategy" include (achieved up to 2020):

1. an increase in production of small and medium-sized enterprises by $10 \%$;

2. an increase in the number of employers by $15 \%$;

3. an increase in the size of manufacturing by $7 \%$.

What is more, the main objectives for development strategy of small and medium-sized enterprises in Georgia include:

- an increase in competitiveness for small and medium enterprises on the local and international markets;

- the development of entrepreneurial skills and introduction of modern entrepreneurial culture;

- promotion of modernization and technological innovation.

\section{CONCLUSION}

In recent years the government's reforms in Georgia substantially improved the country's business environment significantly reducing administrative barriers and enhancing public services.

As for analysing the "Doing Business Ranking 2013 and 2016" indicators, and by comparing Georgia's data to other countries such as Armenia and the USA and other countries, it could be seen that some indicators have improved, some did not change. Especially "Protecting Investors" indicator hasn't been changed at all. It still remains at the same level (20). However, this means that Georgia maintains its stable economic and political situation.

Georgia, as a developing country, has been participating in many international programs. This cooperation and international involvement began to be very intense after the Rose Revolution. Since 2004, Georgia began to climb the international rankings and indices which provided interesting research ground for all kinds of social scientists. Participation in different types of projects and close cooperation with international institutions such as USAID, World Bank and many European institutions and foundations also resulted in a regular and most importantly, credible, monitoring of it situation.

The USAID Projects have been helping to reform Georgian economy for a long time. There are also SME programs, which aim to reduce poverty and boost employment. One of their goals is to strengthen the capacity of Georgia's agricultural sector. Entrepreneurs in this sector have to be able to respond to export opportunities. 
Nevertheless, in order to promote the development of Georgia's small and medium-sized enterprises, and in order to strengthen the position of SMEs and their competitiveness on local and international markets a number of strategic activities are necessary to be implemented. They include, among other things:

- improvement of legislative, institutional and entrepreneurial environment;

- improvement of an access to finance sector;

- development of employees' skills and enhancement of entrepreneurial culture;

- promotion of different forms of export and SMEs internationalization;

- innovation, research and development.

- improvement of material and immaterial resources

- increase in the labour force

- improvement of information flow among the SMEs.

An important factor in the entrepreneurship environment is political stability. This may be especially important for foreign trade partners and potential investors. In this respect, recent history does not provide a very optimistic picture of Georgia. Political instability is cited as the main obstacle by representatives of small, medium and large companies in Georgia. To sum up, business potential of Georgia can be improved, however it must be done in a planned and coordinated manner.

\section{REFERENCES}

[1] Are EU SMEs recovering from the crisis? Annual Report on EU Small and Medium sized Enterprises 2010/2011, Rotterdam, Cambridge, 2011.

[2] Babych, Y. and M. Fuenfzig. An Application of the Growth Diagnostics Framework: The Case of Georgia (Working Paper No. 001-12). International School of Economics at TSU, Tbilisi, Republic of Georgia, 2012, http://ideas.repec.org/p/tbs/wpaper/12-001.html.

[3] Communication From The Commission To The Council, The European Parliament, The European Economic And Social Committee And The Committee Of The Regions, "Think Small First", A "Small Business Act" for Europe, Brussels, 25.6.2008 COM(2008) 394 final

[4] Country programme document for Georgia (2016-2020)

[5] De Clercq D., Sapienza H., Crijns H., The internationalization of small and medium firms, "Small business economics" No. 24/2005, pp. 409-419.

[6] Doing Business 2011, Georgia, Making a difference for Entrepreneurs, The World Bank, 2011.

[7] Entrepreneurship and Small and medium-sized enterprises (SMEs) in EU, http://ec.europa.eu/growth/smes

[8] EUROPE 2020, A Strategy For Smart, Sustainable And Inclusive Growth, Communication From The Commission, Brussels, 3.3.2010, $\operatorname{COM(2010)~} 2020$.

[9] European Commission, Impact Assessment Guidelines, 15 January 2009, SEC(2009) 92.

[10] Evaluation of The Application of The Think Small First Principle in EU Legislation And Programmes, Specific Contract Reference: Entr/E4/04/93/1/08/17, Framework Contract On Evaluations Entr/04/093, Lot 1.

[11] Final report - Annual Report on European SMEs - 2014/2015 - SMEs start hiring again. http://ec.europa.eu/DocsRoom/documents/16341/attachments/2/translations 
[12] Final Report of the Expert Group on Supporting the Internationalization of SMEs, Enterprise And Industry Directorate-General, December 2007.

[13] http://www.eib.org/attachments/efs/economic_report_neighbourhood_sme_financing_georgia_en.pdf

[14] http://www.ge.undp.org/content/dam/georgia/docs/strategicdocs/UNDP_GE_CPD_2016-2020.pdf

[15] Lisbon Strategy for Growth and Jobs, 2000.

[16] Neighbourhood SME financing: Georgia, report, Ferbruary, 2016. European Investment Bank.

[17] OECD Framework for the Evaluation of SME and Entrepreneurship, Policies and Programmes, OECD 2007.

[18] Olesiński Z., Rzepka A., Sabat A., Sieci powiazań we wspótczesnej gospodarce, Texters, Warszawa 2016

[19] Promoting Entrepreneurship And Innovative Smes In A Global Economy: Towards A More Responsible And Inclusive Globalization, Istanbul, Turkey 3-5 june 2004

[20] Rzepka A., Masurashvili I., Current state of the Business Administration in Georgia and his role in Global Economy, ScieConf2014. pp. 79-84.

[21] SME Test Benchmark, Acontribution To The European Commission's Reflections On Strengthening The Sme Test, Eurochambres Report, November 2011.

[22] The 2010 State of the Union, http://www.huffingtonpost.com, 2011.

[23] The Global Competitiveness Report 2011-12

[24] The Global Innovation Index 2011, INSEAD, 2011.Final Report of the Expert Group on Supporting the internationalization of SMEs, European Commission, Enterprise And Industry Directorate-General, 2007.

[25] The World in 2050. The Accelerating Shift of Global Economic Power: Challenges and Opportunities, PWC, 2011.

[26] USA SBA Strategic Plan - Fiscal Years 2011 - 2016.

\section{PERSPEKTYWY STRATEGICZNE DLA BIZNESU W GRUZJI -ANALIZA PRZED- SIĘBIORSTW ŚREDNIEJ WIELKOŚCI W UNII EUROPEJSKIEJ ORAZ GRUZJI}

Małe i średnie przedsiębiorstwa (MŚP) są jednym z najważniejszych motorów rozwoju gospodarczego. Określają one wytrzymałość systemu ekonomicznego danego kraju i stanowią główne źródło tworzenia miejsc pracy. MŚP mogą być traktowane jako katalizator dla wzrostu gospodarczego, które przyczyniają się do efektywnego wykorzystania ograniczonych zasobów we współpracy z dużymi firmami MŚP wpływają na wzrost produktu krajowego brutto, a ponadto przyczyniają się do powstawania klasy średniej, zwiększenia stabilności gospodarczej i politycznej. Ponadto małe i średnie przedsiębiorstwa odgrywają kluczową rolę $\mathrm{w}$ relacjach biznesowych. Silne i dobrze rozwinięty sektor małych i średnich przedsiębiorstw w znacznym stopniu przyczyniają się do eksportu, innowacji, w celu stworzenia nowoczesnej kultury przedsiębiorczości, a jednocześnie odgrywają ważną rolę w podnoszeniu poziomu dobrobytu kraju.

Skierowanie wsparcia do sektora MŚP należy uznać za trafne wobec specyficznych dla gruzińskiej gospodarki, potrzeb i wyzwań. Rozwój przedsiębiorczości stanowi konieczny warunek demokratyzacji. Jednym z głównych problemów małej przedsiębiorczości jest bardzo ograniczony dostęp do finansowania zewnętrznego, co stanowi nieprzekraczalną barierę dla inwestycji i rozwoju firm w początkowym okresie działalności. Z drugiej strony jednak, Gruzja należy do światowych liderów, jeśli chodzi o tworzenie przyjaznych warunków prawnych dla MSP. Mała i średnia przedsiębiorczość jest więc nie tylko obszarem, którego wsparcia odpowiada 
na gruzińskie problemy, ale również tym, który przy sprzyjających okolicznościach, może okazać się największą gruzińską siłą.

W pierwszej części artykułu autorzy przedstawili doświadczenia MŚP w Unii Europejskiej, w drugiej części zaś omówili główne kierunki rozwoju MŚP w Gruzji na podstawie analizy danych statystycznych. Artykuł kończy się konkluzjami uwzględniającymi strategiczne priorytety rozwoju MSP w Gruzji.

Słowa kluczowe: MSP, biznes globalny, konkurencyjność, Gruzja, przedsiębiorczość

DOI: $10.7862 /$ rz.2016.mmr.31

Tekst złożono w redakcji: maj 2016

Przyjęto do druku: wrzesień 2016 
